\author{
P.R. Mammadli ${ }^{1}$, L.F. Mashadiyeva ${ }^{2}$, Z.T. Hasanova ${ }^{3}$, D.M. Babanly ${ }^{1,2}$
}

\title{
Thermodynamic Study of a Synthetic Analog of the Famatinite Mineral - $\mathrm{Cu}_{3} \mathrm{SbS}_{4}$
}

\author{
${ }^{1}$ Azerbaijan State Oil and Industry University, French-Azerbaijani University (UFAZ), Baku, Azerbaijan, \\ parvin.mammadli@ufaz.az \\ ${ }^{2}$ Institute of Catalysis and Inorganic Chemistry named after acad. M. Nagiyev, Azerbaijan National Academy of Sciences, \\ Baku, Azerbaijan \\ ${ }^{3}$ Baku State University, Baku, Azerbaijan
}

\begin{abstract}
Fundamental thermodynamic properties of the synthetic analog of the famatinite mineral $-\mathrm{Cu}_{3} \mathrm{SbS}_{4}$ were studied on the basis of electromotive force (EMF) measurements. The EMF of the concentration chains relative to the $\mathrm{Cu}$ electrode with a solid electrolyte was measured for the alloys from the $\mathrm{Cu}_{3} \mathrm{SbS}_{4}+\mathrm{Sb}_{2} \mathrm{~S}_{3}+\mathrm{S}$ phase region at $300-380 \mathrm{~K}$ temperature interval. Based on measurement data, the relative partial thermodynamic functions of copper in alloys, the standard thermodynamic functions of formation, as well as, the standard entropy of the $\mathrm{Cu}_{3} \mathrm{SbS}_{4}$ ternary compound were calculated for the first time.
\end{abstract}

Keywords: famatinite mineral, $\mathrm{Cu}_{3} \mathrm{SbS}_{4}, \mathrm{EMF}$ method, $\mathrm{Cu}_{4} \mathrm{RbCl}_{3} \mathrm{I}_{2}$ solid electrolyte, thermodynamic functions.

Received 22 January 2021; Accepted 10 February 2021.

\section{Introduction}

The preparation and design of environmentally friendly, earth-abundant, cost-efficient functional materials have received much attention in recent years. From this perspective, copper antimony sulfides (CAS) are being intensively studied as functional materials possessing remarkable properties such as low fabrication temperature, low thermal conductivity, suitable optical band gap, high absorption coefficient, high thermoelectric figure of merit, etc. [1-6].

CAS exist in 4 major phases: chalcostibite $\left(\mathrm{CuSbS}_{2}\right)$, skinnerite $\left(\mathrm{Cu}_{3} \mathrm{SbS}_{3}\right)$, famatinite $\left(\mathrm{Cu}_{3} \mathrm{SbS}_{4}\right)$ and tetrahedrite $\quad\left(\mathrm{Cu}_{12+\mathrm{x}} \mathrm{Sb}_{4+\mathrm{y}} \mathrm{S}_{13}, \quad 0 \leq \mathrm{x} \leq 1.92 \quad\right.$ and $0.02 \leq \mathrm{y} \leq 0.27$ ) occurring naturally as minerals in the Earth's crust [7, 8]. These compounds and phases on their base are promising initial materials for the development of various functional materials to be applied in electronics and high technologies. Particularly, famatinite mineral is considered to be up-and-coming material for thin-film heterojunction solar cells owing to its direct optical band gap in the range of $0.4-1.0 \mathrm{eV}$, high optical absorption co-efficient $\left(\alpha>10^{4} \mathrm{~cm}^{-1}\right)$, and p-type electrical conductivity $[9,10]$. This compound with its reported dimensionless figure of merit 0.14 at $623 \mathrm{~K}$ is also a promising thermoelectric material $[11,12]$. There are numerous works dedicated to the synthesis and characterization of $\mathrm{Cu}_{3} \mathrm{SbS}_{4}$ microflowers [13], nanofibers [14], nanocrystals [15, 16], and thin films [9, $17,18]$.

Thermodynamic data in combination with phase diagrams are very important for the development of directed synthesis and design methods of complex phases and materials [19-20]. One of the well-reasoned ways of obtaining such data sets is associated with the use of the EMF method, which allows coordinating the study of phase equilibria and thermodynamic properties [21-23]. Similar complex studies were carried out by various modifications of the EMF method [24-27]. Particularly, the EMF method with solid $\mathrm{Cu}^{+}$conducting electrolyte is successfully applied to the thermodynamic study ternary and more complex copper-based chalcogenide systems [24, 28-31]. 
Despite the fact that the famatinite mineral is considered to be a promising base material for the development and design of new generation functional materials, its thermodynamic properties have almost not been studied. Only by authors of [32], the Gibbs free energy for the formation of the famatinite mineral by the interaction of tetrahedrite with sulfur vapour was reported.

Considering above mentioned facts, the present contribution is devoted to the thermodynamic study of the $\mathrm{Cu}_{3} \mathrm{SbS}_{4}$ compound.

\section{Experimental part}

The following electrochemical cell was composed for thermodynamic studies:

(-) $\mathrm{Cu}$ (solid) $\mid \mathrm{Cu}_{4} \mathrm{RbCl}_{3} \mathrm{I}_{2}$ (solid) $\mid(\mathrm{Cu}$ in alloys)(solid)(+) (1)

in which the $\mathrm{Cu}_{4} \mathrm{RbCl}_{3} \mathrm{I}_{2}$ compound served as a solid electrolyte. It was synthesized by fusing stoichiometric amounts of chemically pure, anhydrous $\mathrm{CuCl}, \mathrm{CuI}$, and $\mathrm{RbCl}$ in an evacuated $\left(\sim 10^{-2} \mathrm{~Pa}\right)$ quartz ampoule at $900 \mathrm{~K}$ with subsequent cooling to $450 \mathrm{~K}$ and thermal treatment at this temperature for $\sim 100 \mathrm{~h}[23,24]$. From the obtained cylindrical ingot with a diameter of $\sim 6 \mathrm{~mm}$, tablets with a thickness of $2-3 \mathrm{~mm}$ were cut out, which were used as a solid electrolyte in chains of type (1).

For the selection of the composition of the right electrodes, we have used the solid-phase diagram of the $\mathrm{Cu}-\mathrm{Sb}-\mathrm{S}$ system $[8,33]$. According to that diagram, the ray line from the copper apex of the triangle passes through the stoichiometric composition of the $\mathrm{Cu}_{3} \mathrm{SbS}_{4}$ compound and enter the $\mathrm{Cu}_{3} \mathrm{SbS}_{4}+\mathrm{Sb}_{2} \mathrm{~S}_{3}+\mathrm{S}$ three-phase region. Therefore, for the thermodynamic study of this compound in the concentration chains relative to the $\mathrm{Cu}$ electrode, it is expedient to use alloys from this phase region as the right electrode [23, 24].
Initial compounds $\mathrm{Sb}_{2} \mathrm{~S}_{3}$ and $\mathrm{Cu}_{3} \mathrm{SbS}_{4}$ were synthesized to prepare the right electrodes of the electrochemical cell of the type (1). Simple substances of high purity from Evochem Advanced Materials $\mathrm{GmbH}$ (Germany) were used for synthesis: copper granules (Cu-00029; 99.9999\%), antimony granules (Sb-00002; 99.999\%), sulphur pieces (S-00001; 99.999\%). Compounds were synthesized by fusion of the stoichiometric amounts of the corresponding elements in evacuated $\left(\sim 10^{-2} \mathrm{~Pa}\right)$ and sealed quartz ampoules in a two-zone inclined furnace. The temperature of the upper, "cold" zone of the furnace was $650 \mathrm{~K}$, which is slightly below the boiling point of sulphur (718 K) [34] and the lower "hot zone" was $30-50^{\circ}$ higher than the melting point of the synthesized compound. After synthesis, the ampoules were kept at $750 \mathrm{~K}$ for $100 \mathrm{~h}$.

The individuality of the synthesized compounds was controlled by the differential thermal analysis (DTA) and the powder X-ray diffraction (PXRD) technique. DTA of the samples was carried out in evacuated quartz ampoules on a differential scanning calorimeter 404 F1 Pegasus System (NETZSCH). X-ray analysis of the annealed alloys was carried out at room temperature on the Bruker D2 PHASER diffractometer with $\mathrm{CuK}_{\alpha 1}$ radiation. Diffraction patterns of the $\mathrm{Sb}_{2} \mathrm{~S}_{3}$ and $\mathrm{Cu}_{3} \mathrm{SbS}_{4}$ compounds were found to be identical with the ones given in the database of the Bruker software.

Alloys were prepared by fusing pre-synthesized $\mathrm{Cu}_{3} \mathrm{SbS}_{4}$ and $\mathrm{Sb}_{2} \mathrm{~S}_{3}$ compounds with $1-2$ at.\% excess of the elemental sulfur in $\mathrm{Cu}_{3} \mathrm{SbS}_{4}: \mathrm{Sb}_{2} \mathrm{~S}_{3}$ and $\mathrm{Cu}_{3} \mathrm{SbS}_{4}$ : $2 \mathrm{Sb}_{2} \mathrm{~S}_{3}$ molar ratios in evacuated quartz ampoules. The total mass of samples was $1 \mathrm{~g}$ and they were subjected to stepwise homogenizing thermal annealing: at first, they were kept below the $\mathrm{Cu}_{3} \mathrm{SbS}_{4}-2 \mathrm{Sb}_{2} \mathrm{~S}_{3}$ eutectics $(740 \mathrm{~K}$ [33] $(700 \mathrm{~K})$ for 800 hours, and then at $380 \mathrm{~K}$ for $100 \mathrm{~h}$. Phase compositions of the synthesized alloys were confirmed by the PXRD method. The powder XRD pattern of the sample with the $\mathrm{Cu}_{3} \mathrm{SbS}_{4}+2 \mathrm{Sb}_{2} \mathrm{~S}_{3}$ composition with $\sim 1$ at. $\%$ sulfur excess is given in Fig. 1 .

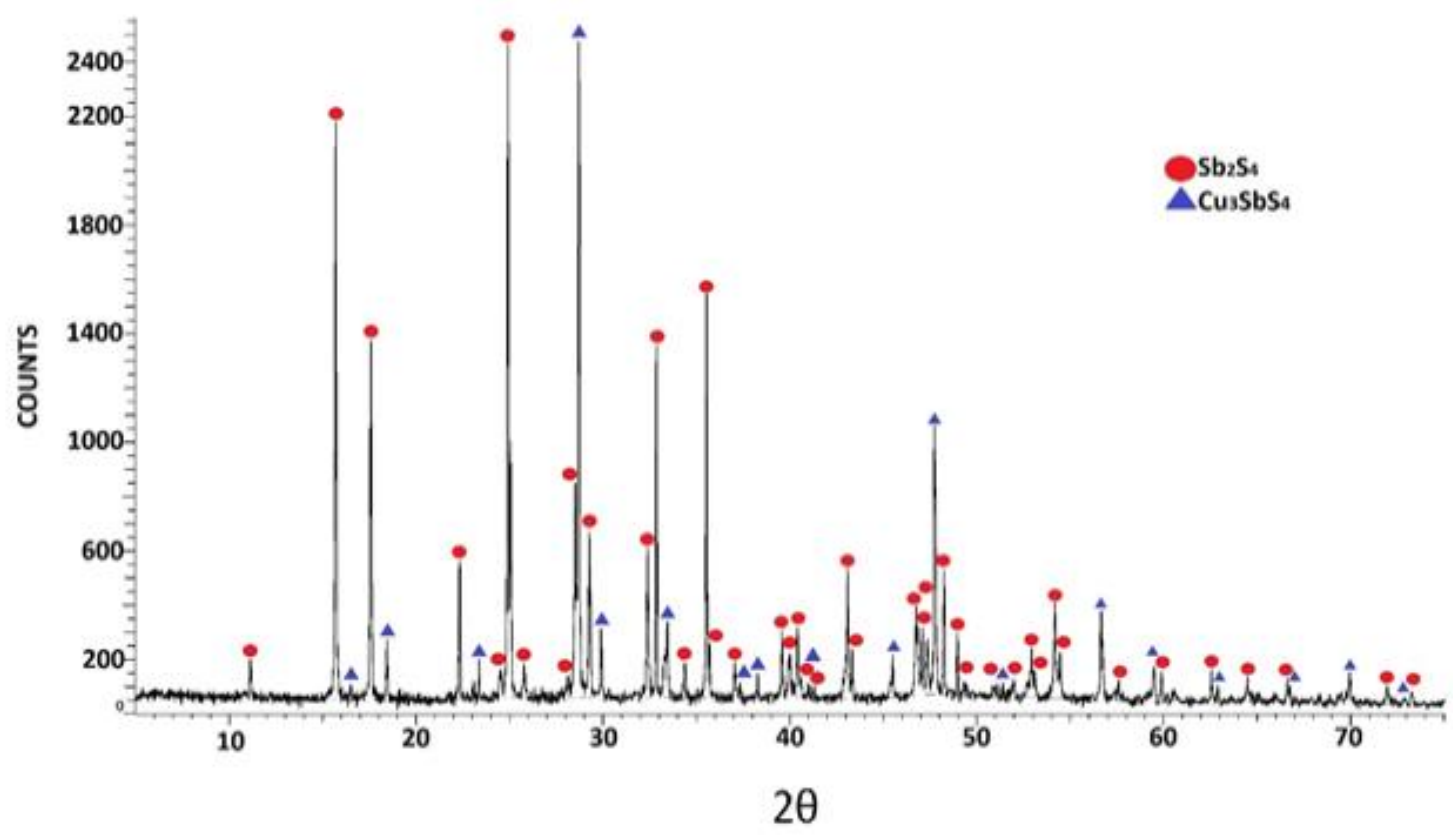

Fig. 1. PXRD pattern of the sample from the $\mathrm{Cu}_{3} \mathrm{SbS}_{4}+\mathrm{Sb}_{2} \mathrm{~S}_{3}+\mathrm{S}$ phase area of the Cu-Sb-S system. 
As it is seen from the figure, this diffraction pattern consists of the diffraction lines belonging to the $\mathrm{Cu}_{3} \mathrm{SbS}_{4}$ and $\mathrm{Sb}_{2} \mathrm{~S}_{3}$ compounds. The absence of the diffraction lines related to sulfur is associated with its negligible amount in this alloy (Fig. 1). Right electrodes were prepared by compressing powder of the annealed alloys in the form of tablets $\sim 6 \mathrm{~mm}$ in diameter and $2-3 \mathrm{~mm}$ in thickness. 1 - $2 \mathrm{~mm}$ thick plate of copper metal of high purity was used as a left electrode.

The procedure for assembling an electrochemical cell and measuring the EMF is detailed in [24, 25]. EMF measurements were carried at the 300-380 K temperature interval using a high-resistance digital voltmeter "2100 6 $1 / 2$ Digit Multimeter" (Keithley). In the mentioned temperature range, all phases of the studied alloys, including elemental sulphur are in the solid state and their compositions are practically independent of the temperature. Initial equilibrium values of the EMF were obtained after holding the cell at $\sim 350 \mathrm{~K}$ for $40-60 \mathrm{~h}$, and successive values were taken every 3 - 4 hours after a certain temperature was maintained. Equilibrium values were considered the EMF readings that varied by no more than $0.5 \mathrm{mV}$ irrespective of the direction of temperature change at repeated measurements at a given temperature. All necessary precautions to ensure the reversibility of concentration chains of the type (1) have been taken during measurements [22-24].

\section{Results and discussion}

The EMF measurements of the chains type (1) led to reproducible results. Measurements showed that the EMF values of both right electrodes well-coincide with each other and are linear functions of temperature (Fig. 2). Therefore, for thermodynamic calculations, the data of the EMF measurements were processed by the leastsquares method using a special computer program, and a linear equation of the following type was obtained [2224]:

$$
\mathrm{E}=\mathrm{a}+\mathrm{bT} \pm \mathrm{t}\left[\left(S_{E}^{2} / \mathrm{n}\right)+S_{b}^{2} \cdot\left(T-\bar{T}^{2}\right]^{1 / 2},\right.
$$

where $n$ is the number of pairs of $E$ and $T$ values; $S_{E}$ and $S_{b}$ are the error variances of the EMF readings and $b$ coefficient, respectively; $\overline{\mathrm{T}}$ is the average of the absolute temperature; $t$ is Student's test. At the confidence level of $95 \%$ and $n \geq 20$, Student's test is $t \leq 2$ [22-24]. The results of EMF measurements and calculations are given in Table 1 .

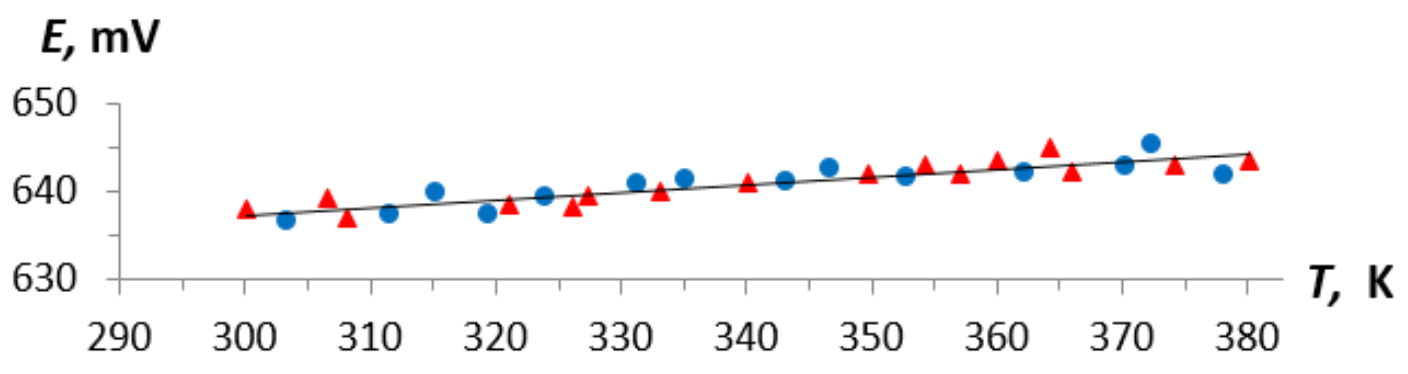

Fig. 2. Temperature dependences of EMF of the chains type (1) for the $\mathrm{Cu}_{3} \mathrm{SbS}_{4}+\mathrm{Sb}_{2} \mathrm{~S}_{3}+\mathrm{S}$ phase area of the $\mathrm{Cu}-\mathrm{Sb}-\mathrm{S}$ system.

Table 1

Experimental results and their computer processing to obtain a linear equation of the type (2) for the temperature dependences of the EMF

\begin{tabular}{|c|c|c|c|c|c|c|c|}
\hline $\mathrm{T}_{\mathrm{i}}, \mathrm{K}$ & $\mathrm{E}_{\mathrm{i}}, \mathrm{mV}$ & $\mathrm{T}_{\mathrm{i}}-\overline{\mathrm{T}}$ & $\mathrm{E}_{\mathrm{i}}\left(\mathrm{T}_{\mathrm{i}}-\overline{\mathrm{T}}\right)$ & $\left(\mathrm{T}_{\mathrm{i}}-\overline{\mathrm{T}}\right)^{2}$ & $\tilde{\mathrm{E}}$ & $\mathrm{E}_{\mathrm{i}}-\tilde{\mathrm{E}}$ & $\left(\mathrm{E}_{\mathrm{i}}-\tilde{\mathrm{E}}\right)^{2}$ \\
\hline 300.1 & 638.02 & -40.98 & -26143.93 & 1679.09 & 637.40 & 0.62 & 0.38 \\
\hline 303.2 & 636.89 & -37.88 & -24123.27 & 1434.64 & 637.67 & -0.78 & 0.61 \\
\hline 306.5 & 639.19 & -34.58 & -22101.06 & 1195.55 & 637.96 & 1.23 & 1.51 \\
\hline 308.1 & 637.01 & -32.98 & -21006.47 & 1087.46 & 638.10 & -1.09 & 1.19 \\
\hline 311.4 & 637.51 & -29.68 & -18919.17 & 880.70 & 638.39 & -0.88 & 0.77 \\
\hline 315.2 & 639.98 & -25.88 & -16560.55 & 669.60 & 638.72 & 1.26 & 1.59 \\
\hline 319.4 & 637.58 & -21.68 & -13820.61 & 469.88 & 639.09 & -1.51 & 2.27 \\
\hline 321.1 & 638.65 & -19.98 & -12758.10 & 399.07 & 639.23 & -0.58 & 0.34 \\
\hline 323.8 & 639.54 & -17.28 & -11049.12 & 298.48 & 639.47 & 0.07 & 0.00 \\
\hline 326.1 & 638.25 & -14.98 & -9558.86 & 224.30 & 639.67 & -1.42 & 2.02 \\
\hline
\end{tabular}


Table 1

(continuation)

Experimental results and their computer processing to obtain a linear equation of the type (2) for the temperature dependences of the EMF

\begin{tabular}{|c|c|c|c|c|c|c|c|}
\hline $\mathrm{T}_{\mathrm{i}}, \mathrm{K}$ & $\mathrm{E}_{\mathrm{i}}, \mathrm{mV}$ & $\mathrm{T}_{\mathrm{i}}-\overline{\mathrm{T}}$ & $\mathrm{E}_{\mathrm{i}}\left(\mathrm{T}_{\mathrm{i}}-\overline{\mathrm{T}}\right)$ & $\left(\mathrm{T}_{\mathrm{i}}-\overline{\mathrm{T}}\right)^{2}$ & $\tilde{\mathrm{E}}$ & $\mathrm{E}_{\mathrm{i}}-\tilde{\mathrm{E}}$ & $\left(E_{i}-\tilde{E}\right)^{2}$ \\
\hline 327.3 & 639.56 & -13.78 & -8811.00 & 189.80 & 639.78 & -0.22 & 0.05 \\
\hline 331.2 & 640.98 & -9.88 & -6330.75 & 97.55 & 640.12 & 0.86 & 0.75 \\
\hline 333.1 & 640.12 & -7.98 & -5106.02 & 63.63 & 640.28 & -0.16 & 0.03 \\
\hline 335.1 & 641.56 & -5.98 & -3834.39 & 35.72 & 640.46 & 1.10 & 1.22 \\
\hline 340.2 & 640.98 & -0.88 & -561.93 & 0.77 & 640.90 & 0.08 & 0.01 \\
\hline 343.1 & 641.25 & 2.02 & 1297.46 & 4.09 & 641.15 & 0.10 & 0.01 \\
\hline 346.6 & 642.86 & 5.52 & 3550.73 & 30.51 & 641.46 & 1.40 & 1.96 \\
\hline 349.8 & 642.02 & 8.72 & 5600.55 & 76.10 & 641.74 & 0.28 & 0.08 \\
\hline 352.7 & 641.85 & 11.62 & 7460.44 & 135.10 & 641.99 & -0.14 & 0.02 \\
\hline 354.3 & 642.95 & 13.22 & 8501.94 & 174.86 & 642.13 & 0.82 & 0.67 \\
\hline 357.1 & 642.02 & 16.02 & 10287.30 & 256.75 & 642.38 & -0.36 & 0.13 \\
\hline 360.1 & 643.65 & 19.02 & 12244.37 & 361.89 & 642.64 & 1.01 & 1.03 \\
\hline 362.1 & 642.35 & 21.02 & 13504.34 & 441.98 & 642.81 & -0.46 & 0.21 \\
\hline 364.2 & 644.96 & 23.12 & 14913.63 & 534.69 & 642.99 & 1.97 & 3.86 \\
\hline 366 & 642.26 & 24.92 & 16007.26 & 621.17 & 643.15 & -0.89 & 0.80 \\
\hline 370.1 & 643.01 & 29.02 & 18662.29 & 842.35 & 643.51 & -0.50 & 0.25 \\
\hline 372.2 & 645.65 & 31.12 & 20094.78 & 968.66 & 643.69 & 1.96 & 3.83 \\
\hline 374.1 & 643.01 & 33.02 & 21234.33 & 1090.54 & 643.86 & -0.85 & 0.72 \\
\hline 378 & 642.15 & 36.92 & 23710.32 & 1363.33 & 644.20 & -2.05 & 4.20 \\
\hline 380.1 & 643.51 & 39.02 & 25111.91 & 1522.82 & 644.38 & -0.87 & 0.76 \\
\hline $\bar{T}=341.08$ & $\bar{E}=640.98$ & & & & & & \\
\hline
\end{tabular}

The obtained equation of the type (2) for the mentioned phase region is given below:

$$
611.22+0.0872 T \pm 2\left[\frac{1,1}{30}+6.1 \cdot 10^{-5}(T-341.1)^{2}\right]^{1 / 2}
$$

The relative partial molar functions of copper in the alloys were calculated by using this equation, and the following thermodynamic relations [23, 24]:

$$
\begin{gathered}
\Delta \bar{G}_{C u}=-z F E \\
1 \Delta \bar{H} C u=-z\left[E-T\left(\frac{\partial E}{\partial T}\right)_{P}\right]=-z F a \\
\Delta \bar{S}_{C u}=z F\left(\frac{\partial E}{\partial T}\right)_{P}=z F b
\end{gathered}
$$

The calculation of the relative partial molar functions of copper from the equation of the temperature dependence of the EMF in $\mathrm{Cu}_{3} \mathrm{SbS}_{4}+\mathrm{Sb}_{2} \mathrm{~S}_{3}+\mathrm{S}$ phase region gave the quantities:

$$
\begin{aligned}
\Delta \bar{G}_{C u} & =-61.48 \pm 0.07 \mathrm{~kJ} \cdot \mathrm{mol}^{-1} \\
\Delta \bar{H}_{C u} & =-58.97 \pm 0.51 \mathrm{~kJ} \cdot \mathrm{mol}^{-1}
\end{aligned}
$$

$$
\Delta \bar{S}_{C u}=8.42 \pm 1.50 \mathrm{~J} \cdot \mathrm{mol}^{-1} \cdot \mathrm{K}^{-1}
$$

Potential forming reaction per unit formula of the $\mathrm{Cu}_{3} \mathrm{SbS}_{4}$ compound was composed using the solid-phase equilibria diagram of the $\mathrm{Cu}-\mathrm{Sb}-\mathrm{S}$ system, based on the well-known technique [22-24] for determination of the total potential-forming reactions in concentration chains:

$$
3 \mathrm{Cu}+0.5 \mathrm{Sb}_{2} S_{3}+2.5 \mathrm{~S}=\mathrm{Cu}_{3} \mathrm{SbS}_{4}
$$

In this equation, all substances are in a crystalline state, since the upper-temperature limit of EMF measurements $(380 \mathrm{~K})$ does not exceed the melting point of the most fusible component - sulphur.

The standard thermodynamic functions of formation $\mathrm{Cu}_{3} \mathrm{SbS}_{4}$ were calculated based on the reaction (8) according to the following ratios:

$$
\Delta_{f} Z^{0}\left(C u_{3} S b S_{4}\right)=3 \Delta \bar{Z}_{\mathrm{Cu}}+0.5 \Delta_{f} Z^{0}\left(S b_{2} S_{3}\right),
$$

where $\Delta_{f} Z^{0}$ is the standard Gibbs free energy $\Delta_{f} G^{0}$ and standard enthalpy of formation $\Delta_{f} H^{0}$ for the corresponding compound. The standard entropy of the $\mathrm{Cu}_{3} \mathrm{SbS}_{4}$ was calculated as: 
Standard integral thermodynamic functions for the $\mathrm{Sb}_{2} \mathrm{~S}_{3}$ and $\mathrm{Cu}_{3} \mathrm{SbS}_{4}$ compounds

\begin{tabular}{|c|c|c|c|c|}
\hline \multirow{2}{*}{ Compound } & $-\Delta_{f} G^{0}$ & $-\Delta_{f} H^{0}$ & $\mathrm{~S}^{\text {o }}$ & \multirow{2}{*}{ Ref. } \\
\cline { 2 - 5 } & \multicolumn{2}{|c|}{$\mathrm{kJ} / \mathrm{mol}$} & $\mathrm{J} /(\mathrm{mol} \cdot \mathrm{K})$ & {$[35]$} \\
\hline \multirow{3}{*}{$\mathrm{Sb}_{2} \mathrm{~S}_{3}$} & 140.29 & 141.80 & 182.17 & {$[36]$} \\
\cline { 2 - 5 } & $140.5 \pm 4.2$ & $141.8 \pm 4.1$ & $182.0 \pm 3.3$ & {$[37]$} \\
\hline $\mathrm{Cu}_{3} \mathrm{SbS}_{4}$ & 156.08 & 157.74 & $295.6 \pm 7.0$ & This work \\
\hline
\end{tabular}

$$
\begin{aligned}
& S^{0}\left(\mathrm{Cu}_{3} \mathrm{SbS}_{4}\right)=3 \Delta \bar{S} \mathrm{Cu}+3 \mathrm{~S} 0(\mathrm{Cu})+ \\
& \quad+2.5 S^{0}(S)+0.5 S^{0}\left(\mathrm{Sb}_{2} S_{3}\right)
\end{aligned}
$$

Calculated integral thermodynamic functions of the $\mathrm{Cu}_{3} \mathrm{SbS}_{4}$ compound are given in Table 2. During calculations according to the reaction (8), we used the values of the standard entropies of copper $\left(\mathrm{S}^{0}=33.15 \pm 0.08 \mathrm{~J} \cdot \mathrm{mol}^{-1} \cdot \mathrm{K}^{-1}\right) \quad$ and sulphur $\left(\mathrm{S}^{0}=31.92 \pm 0.21 \mathrm{~J} \cdot \mathrm{mol}^{-1} \cdot \mathrm{K}^{-1}\right) \quad[34]$, as well as, the standard integral thermodynamic functions of $\mathrm{Sb}_{2} \mathrm{~S}_{3}$. The reference data for $\mathrm{Sb}_{2} \mathrm{~S}_{3}$ are also listed in Table 2. As can be seen, the values recommended in the reference book [35] coincide with the results of [36], while the data given in the database [37] differ significantly from them. We used the data from [36] since the values given in [37] are based on earlier sources.

\section{Conclusion}

For the first time, the relative partial molar functions of copper in alloys from the $\mathrm{Cu}_{3} \mathrm{SbS}_{4}+\mathrm{Sb}_{2} \mathrm{~S}_{3}+\mathrm{S}$ phase region on the phase diagram have been calculated using the EMF measurements of the concentration chains of type (1) at $300-380 \mathrm{~K}$ temperature interval. Based on the solid-phase equilibria diagram, the equation of the potential-forming reaction for the $\mathrm{Cu}_{3} \mathrm{SbS}_{4}$ compound was determined, and its standard thermodynamic functions of formation and standard entropy were calculated.

\section{Acknowledgment}

The work has been partially supported by the Science Development Foundation under the President of the Republic of Azerbaijan, a grant EIF-BGM-4-RFTF1/2017-21/11/4-M-12.

On behalf of all authors, the corresponding author states that there is no conflict of interest.

Mammadli P.R. - PhD student on Chemistry, chemistry teacher;

Mashadiyeva L.F. - $\mathrm{PhD}$ on Chemistry, Associate Professor, Senior Researcher;

Hasanova Z.T. - PhD student on Chemistry, scientific researcher of the "Inorganic Materials Science" laboratory;

Babanly D.M. - Dr. of Sciences on Chemistry, Lecturer, Senior Researcher.

[1] E. Peccerillo, K. Durose, MRS Energy \& Sustainability, 5(13), 1 (2018) (https://doi.org/10.1557/mre.2018.10).

[2] B. Krishnan, S. Shaji, R. Ernesto Ornelas, J. Mater. Sci.: Mater. Electron 26(7), 4770 (2015) (https://doi.org/10.1007/s10854-015-3092-2).

[3] F.E. Loranca-Ramos, C.J. Diliegros-Godines, R. Silva González, M. Pal, Appl. Surf. Sci. 427, 1099 (2018) (https://doi.org/10.1016/j.apsusc.2017.08.027).

[4] R. Chetty, A. Bali, R.C. Mallik, J. Mater. Chem. C. 3, 12364 (2015) (https://doi.org/10.1039/C5TC02537K).

[5] X. Lu, D.T. Morelli, Y. Xia, F. Zhou, V. Ozolins, H. Chi, X. Zhou, C. Uher, Adv. Energy Mater. 3(3), 342 (2013) (https://doi.org/10.1002/aenm.201200650).

[6] M.H.K. Rabinal, R. Mulla, Energy Technology, 7(7), 1800850 (https://doi.org/10.1002/ente.201800850).

[7] Mindat.org: Open database of minerals, rocks, meteorites, and the localities they come from. Available at http://www.mindat.org (accessed August 23, 2018).

[8] B.J. Skinner, F.D. Luce, E. Makovicky, Econ. Geol. 67(7), 924 (http://dx.doi.org/10.2113/gsecongeo.67.7.924).

[9] U. Chalapathi, B. Poornaprakash, S.-H. Park, Ceramics International 43(6), 5229 (2017) (https://doi.org/10.1016/j.ceramint.2017.01.048).

[10] J. Li, X. Han, J. Li, Y. Zhao, C. Fan, Phys. Status Solidi B 254(5), 1600608 (2016) (https://doi.org/10.1002/pssb.201600608).

[11] G.-E. Lee, J.-H. Pi, I.-H. Kim, J. Electron. Mater. 49(5), 2781 (2019) (https://doi.org/10.1007/s11664-01907765-8).

[12] Q. Wang, J. Li, J. Li, Phys. Chem. Chem. Phys. 20(3), 1460 (2018) (https://doi.org/10.1039/C7CP06465A).

[13] K. Aup-Ngoen, T. Thongtem, S. Thongtem, Mater. Lett., 66(1), 182 (2012) (http://dx.doi.org/10.1016/j.matlet.2011.08.035).

[14] C. An, Y. Jin, K. Tang, Y. Qian, J. Mater. Chem. 13(2), 301 (2003) (https://doi.org/10.1039/B210703A).

[15] J. van Embden, Y. Tachibana, J. Mater. Chem. 22(23), 11466 (2012) (https://doi.org/10.1039/C2JM32094K). 
[16] J. van Embden, K. Latham, N.W. Duffy, Y. Tachibana, J. Am. Chem. Soc. 135(31), 11562 (2013) (https://doi.org/10.1021/ja402702x).

[17] P.A. Fernandes, A. Shongalova, A.F. da Cunha, J.P. Teixeira, J.P. Leitão, J.M.V. Cunha, S. Bose, $\begin{array}{lllllll}\text { P.M.P. Salome, M.R. Correia, J. Alloys } & \text { Compd. } & \text { 797, } & 1359 & \text { (2019) }\end{array}$ (https://doi.org/10.1016/j.jallcom.2019.05.149).

[18] A. Azizur Rahman, E. Hossian, H. Vaishnav, J.B. Parmar, A. Bhattacharya, A. Sarma, Mater. Adv. 1(9), 3333 (2020) (https://doi.org/10.1039/D0MA00574F).

[19] R. DeHoff, Thermodynamics in Materials Science, 2nd ed. (CRC Press, 2006).

[20] M.B. Babanly, E.V. Chulkov, Z.S. Aliev, A.V. Shevelkov, I.R. Amiraslanov, Russ. J. Inorg. Chem. 62(13), 1703 (2017) (https://doi.org/10.1134/S0036023617130034).

[21] M.B. Babanly, L.F. Mashadiyeva, D.M. Babanly, S.Z. Imamaliyeva, D.B. Tagiev, Yu.A. Yusibov, Russ. J. Inorg. Chem, 64(13), 1649 (2019) (https://doi.org/10.1134/S0036023619130035).

[22] A.G. Morachevsky, G.F. Voronin, V.A. Geyderich, I.B. Kutsenok, Electrochemical methods of investigation in thermodynamics of metal systems. (Akademkniga Publ, Moscow, 2003).

[23] M.B. Babanly, Yu.A. Yusibov, Electrochemical Methods in Thermodynamics of Inorganic Systems. (Elm, Baku, 2011).

[24] M.B. Babanly, Y.A. Yusibov, N.B. Babanly, Electromotive force and measurement in several systems, Ed. by S. Kara, (Intech, 2011).

[25] N.B. Babanly, E.N.Orujlu, S.Z. Imamaliyeva, Y.A. Yusibov, M.B. Babanly, J. Chem. Thermodynamics, 128, 78 (2019) (https://doi.org/10.1016/j.jct.2018.08.012).

[26] E.G. Osadchii, Y.I. Korepanov, N.N. Zhdanov, Instrum. Exp. Tech. 59(2), 302 (2016) (https://doi.org/10.1134/S0020441216010255).

[27] Z.S. Aliev, S.S. Musayeva, S.Z. Imamaliyeva, M.B. Babanly, J. Therm. Anal. Calorim. 133(2), 1115 (2018) (https://doi.org/10.1007/s10973-017-6812-4).

[28] S.Z. Imamaliyeva, S.S. Musayeva, D.M. Babanly, Y.I. Jafarov, D.B. Tagiyev, M.B. Babanly, Thermochimica Acta 679, 178319 (2019) (https://doi.org/10.1016/j.tca.2019.178319).

[29] I.J. Alverdiyev, Z.S. Aliev, S.M. Bagheri, L.F. Mashadiyeva, Y.A. Yusibov, M.B. Babanly, J. Alloys Compd., 691, 255 (2017) (http://dx.doi.org/10.1016/j.jallcom.2016.08.251).

[30] L.F. Mashadieva, Z.T. Gasanova, Yu.A. Yusibov, M.B. Babanly, Inorg. Mater. 54(1), 8 (2018) (https://doi.org/10.1134/S0020168518010090).

[31] I.J. Alverdiyev, V.A. Abbasova, Y.A. Yusibov, D.B. Tagiyev, M.B. Babanly, Russ. J. Electrochem. 54(2), 153 (2018).

[32] A. Mookherjee, B. Mishra, Mineral. Deposita 19(2), 112 (1984) (https://doi.org/10.1007/BF00204669).

[33] M.B. Babanly, Yu.A. Yusibov, V.T. Abishev, Ternary chalcogenides on the base of copper and silver (In Russian) (BGU, Baku, 1993).

[34] J. Emsley, The elements, 3rd edition (Oxford University Press, Clarendon, 1998).

[35] I. Barin, Thermochemical Data of Pure Substances, 3rd edition (Wiley-VCH, 2008).

[36] G.K. Johnson, G.N. Papatheodorou, C.E. Johnson, J. Chem. Thermodyn. 13(8), 745 (1981) (https://doi.org/10.1016/0021-9614(81)90063-X).

[37] V.S. Iorish and V.S. Yungman, (Eds.) Thermal constants of substances: Database. Version 2 (2006) (http://www.chem.msu.ru/cgi-bin/tkv.pl?show=welcome.html/welcome.html.).

$$
\text { П.Р. Маммадлі }{ }^{1}, \text { Л.Ф.Машадієва }{ }^{2}, 3 . \text { Т. Гасанова }^{3}, \text { Д.М. Бабанли }{ }^{1,2}
$$

\title{
Термодинамічні дослідження синтетичного аналогу мінералу фаматиніту - $\mathrm{Cu}_{3} \mathrm{SbS}_{4}$
}

\footnotetext{
${ }^{1}$ Азербайджсанський державний університет нафти та промисловості, Франиузько-Азербайджанський університет (УФАЗ), Баку, Азербайджан, parvin.mammadli@ufaz.az

${ }^{2}$ Інститут каталізу та неорганічної хімї̈ імені акад. М. Нагієва, Азербайджанська наиіональна академія наук, Баку, Азербайджан

${ }^{3}$ Бакинський державний університет, Баку, Азербайджан
}

\begin{abstract}
Фундаментальні термодинамічні властивості синтетичного аналогу мінералу фаматиніту $\mathrm{Cu}_{3} \mathrm{SbS}_{4}$ вивчалися на основі вимірювань електрорушійної сили (ЕРС). ЕРС ділянок концентрацій відносно Сuелектроду 3 твердим електролітом вимірювали для сплавів із фазової області $\mathrm{Cu}_{3} \mathrm{SbS}_{4}+\mathrm{Sb}_{2} \mathrm{~S}_{3}+\mathrm{S}$ в інтервалі температур 300 - $380 \mathrm{~K}$. На основі даних вимірювань вперше розраховано відносні часткові термодинамічні функції міді в сплавах, стандартні термодинамічні функції утворення, а також стандартна ентропія потрійної сполуки $\mathrm{Cu}_{3} \mathrm{SbS}_{4}$.

Ключові слова: мінерал фаматиніту, $\mathrm{Cu}_{3} \mathrm{SbS}_{4}$, метод EPC, твердий електроліт $\mathrm{Cu}_{4} \mathrm{RbCl}_{3} \mathrm{I}_{2}$, термодинамічні функції.
\end{abstract}

